\title{
Should post-Keynesians make a behavioural turn?
}

\author{
John E. King* \\ School of Economics, La Trobe University, Melbourne, Australia
}

This paper deals with the relationship between post-Keynesian and behavioural economics. I begin by responding critically to Paul Davidson's claim that Keynes was the first behavioural economist. Then I discuss some recent work in behavioural macroeconomics, which reveals some important strengths but also some fundamental weaknesses. Next I outline what (Old) behavioural economists have had to say about macroeconomics, beginning with the father of the school, Herbert Simon, and considering the contributions of some of his disciples. I then reverse the question and ask what post-Keynesians have had to say about behavioural economics, Old and New. I conclude by identifying some potential sources of difficulty and also suggesting some areas of macroeconomics where cooperation between post-Keynesians and behavioural economists seems especially promising.

Keywords: behavioural economics, macroeconomics, post-Keynesian economics

JEL codes: $B 22, B 5, E 12$

\section{INTRODUCTION}

Early in 2010, Therese Jefferson and I submitted a paper with the same title as this one to the Journal of Post Keynesian Economics. Paul Davidson accepted it without requiring any revisions except to the title, which he disliked and insisted on replacing with something blander. The paper was published as the lead article in the Winter 2010-2011 issue of the journal, which was gratifying (Jefferson/King 2010-2011). Unknown to us, he made it part of a mini-symposium. The other contributions were a full-length article by Matthew Fung, who had already published on similar themes in the same journal (Fung 2006), and a short piece by Davidson himself. Fung essentially supported the position that Therese and I had taken, pointing to the considerable amount of common ground shared by post-Keynesians and (Old) behavioural economists and suggesting that more recent developments in (New) behavioural economics could be put to 'productive use' as 'resources' in post-Keynesian macroeconomics (Fung 2010-2011: 247). Davidson's brief contribution, which managed to avoid making any reference to our article, had the title 'Was Keynes the first behavioural economist?'. His answer to this question was a positive one, focusing on the role of uncertainty, conventions and herd behaviour in The General Theory and suggesting that Keynes had anticipated much of the modern work in neuronomics (Davidson 2010-2011).

* I am very grateful to Peter Earl and (especially) Therese Jefferson for extensive comments on an earlier draft. The usual disclaimer applies. 
I am very grateful for an opportunity to revisit the issues raised in the mini-symposium. I take it as read that there is considerable scope for cooperation between (Old) behavioural economists and post-Keynesians on questions of microeconomics. I want instead to explore the more difficult and more interesting question of the relationship between behavioural economists and post-Keynesian macro. ${ }^{1}$ I shall begin (in section 2 ) by providing a rather different answer to Paul Davidson's question concerning Keynes. Then (in section 3) I return to the issue of 'behavioural macroeconomics', which in 2010 Therese and I described as very largely a failure. Two new books with this title shed more light on this subject and seem to me to call for a slight revision of the position that we took in 2010. Section 4 is devoted to what Old behavioural economists have had to say about macroeconomics. I begin with the father of the school, Herbert Simon, and then look at the contributions of some of his disciples, including another fellow-Australian, Peter Earl. ${ }^{2}$ In section 5 I reverse the question, and ask what postKeynesians have had to say about behavioural economics, Old and New. I conclude (in section 6) by identifying some potential sources of difficulty and also suggesting some areas of macroeconomics where cooperation between post-Keynesians and behavioural economists seem especially promising.

\section{WAS KEYNES THE FIRST BEHAVIOURAL ECONOMIST?}

A couple of years ago I approached this question from a slightly different angle, in a paper entitled "Keynes and "psychology" (King 2010). As this was published in an obscure Australian journal and seems to have sunk without trace, I shall summarise it briefly before offering my answer to Davidson's question. There are three distinct problems here. First, what did Keynes know about psychology, and what might he have learned from it in developing his own macroeconomic theory? Second, what use did he make of the terms 'psychology', 'psychological' and 'psychologically' in The General Theory, and in his other writings? Third, did his use of psychological terms and ideas contribute significantly to the development or exposition of his economics?

Keynes was certainly acquainted to some degree with the work of Sigmund Freud, as noted some years ago in several papers by Ted Winslow and, more recently, by the late Gilles Dostaler (Dostaler 2007; Dostaler/Maris 2000; Winslow 1986; 1990). But there is room for doubt about precisely how deep his knowledge of it really was. The handful of references to Freudian psychology in the 30 volumes of the Collected Writings - none of them in The General Theory - are discussed in some detail in King (2010: 2-5, 12), where I conclude that there are strong grounds for scepticism about its influence on Keynes's own economic thinking. He certainly used the words 'psychological', 'psychology' and 'psychologically' in The General Theory: 45 times, 16 times and once, respectively, according to Fred Glahe's invaluable concordance (Glahe 1991).

1. I shall, however, have nothing to say about behavioural finance or experimental economics, both of which deserve serious attention from post-Keynesians. See Fung $(2006 ; 2011)$ and Raines/Leathers (2011) for two rather different perspectives on the first question, and Santos (2011) for a suitably nuanced view of the second.

2. Both Peter Earl and Therese Jefferson have suggested that another Old behavioural economist, George Katona, merits consideration, not least for his work on consumer confidence. There are two excellent recent papers on Katona by Hamid Hosseini (2011) and José Edwards (2012). 
These terms are employed in a variety of contexts and with at least four rather different meanings, conveying subjectivity, stability, individual preferences, and conventionality. Keynes's usage of these words before and after 1936 was less prolific but no less diverse (King 2010: 6-10). My personal conclusion is that Keynes's escape from habitual modes of thought "owed little or nothing to "psychology". The word could be excised from his writings, or replaced by less rhetorically ambitious but more precise terminology, without any loss of meaning', and perhaps with some improvement in clarity of expression (King 2010: 11).

To return to Paul Davidson's question: was Keynes the first behavioural economist? Not really, and with good reason. The Freudian psychology that he knew something about was of little use to him, except as a source of rhetorical tropes, and for the most part these proved to be inconsequential or positively misleading. And his reasons for rejecting the neoclassical view of 'rational' behaviour related much more to the external, macroeconomic environment than to the frailties of the individual human psyche. None the less, it is true that his brief but perceptive remarks on what might constitute 'reasonable' behaviour in a world characterised by fundamental uncertainty - the use of conventions and rules of thumb - are broadly consistent with (Old) behavioural economics. They are certainly inconsistent with both the mainstream concept of unbounded rationality and the irrationality that is posited by some of its (New) behavioural critics.

Perhaps one day a post-Keynesian dramatist will write a one-act play set on a desert island, where Keynes and Herbert Simon have been shipwrecked and have nothing to do while they wait to be rescued other than to argue about the relationship between economics and post-Freudian psychology. Until then, we can only speculate on what Keynes might have made of post-1936 developments in cognitive psychology.

\section{3 'BEHAVIOURAL MACROECONOMICS' REVISITED}

In our original paper, Therese and I were highly critical of behavioural macroeconomics, which, we argued, had made very little progress since it was foreshadowed in George Akerlof's Nobel acceptance speech. His 2009 book, Animal Spirits, co-authored with Robert Shiller, took its title from Keynes but seriously misrepresented the fundamental principles of The General Theory, we maintained. Indeed, it was profoundly nonKeynesian in two important respects. First, it said nothing about the determinants of business investment, and little or nothing about the savings-investment relationship, which in any serious macroeconomic analysis that claims to be 'Keynesian' must play the central role. Second, it completely failed to appreciate the significance for Keynes of fundamental uncertainty, and in consequence also misunderstood his use of the phrase 'animal spirits', which was not synonymous with 'noneconomic motives and irrational behavior'; neither did Keynes argue that animal spirits were 'the main cause of involuntary unemployment' (Akerlof/Shiller 2009: x, cited by Jefferson/King 2010-2011: 218).

I stand by our strong complaints about Animal Spirits, but our critique of the broader behavioural macroeconomics project does require some modification in the light of two new books. First, there is Ian McDonald's new edited book. This contains 24 articles, originally published between 1990 and 2009, and a lucid eight-page introduction by the editor. Several of its ten parts will cause no problems for post-Keynesians, but not much excitement either. It is good to have the involuntary nature of much unemployment confirmed by the findings of happiness research and to find the same literature 
cited in criticism of the supposed benefits of unlimited economic growth (in the two papers in part II and the four in part IX, respectively). The implications of loss aversion and considerations of fairness for the trade-off between unemployment and inflation - a horizontal rather than a vertical Phillips Curve - are much more interesting (see the five papers in Part V). Akerlof's (2007) critique of Ricardian equivalence and the neutrality of money reaches post-Keynesian conclusions via a novel and rather intriguing route, involving the introduction of social norms into individual utility functions (this is the sole paper in part II, and is very much less objectionable than Animal Spirits). And McDonald's own invocation of the 'various biases in human behaviour emphasised in behavioural economics, in particular present bias, self-serving bias, new era stories, money illusion, loss aversion and herding effects' to help explain the Global Financial Crisis is at least part (probably a significant part) of that important story (p. xvi, citing McDonald (2009), which is rather surprisingly the only paper in part VIII).

Other aspects of McDonald's version of behavioural macroeconomics are more worrying. It is not clear to me that 'the growth of an underclass' (the topic of the sole paper in part X) is either an incontestable truth or a macroeconomic phenomenon, while the application of ideas from behavioural economics to produce 'a plan to help people save more' begs several questions (p. xvi, referring to one of the papers in part VII). Even more contentious are the five papers in part IV, which apply the 'efficiency wage' hypothesis to the explanation of money wage rigidity and unemployment. I have no problem with efficiency wage theory as a microeconomic proposition: it has been known for centuries that high wages often induce high productivity and that workers dislike being treated unfairly. Thus there are good reasons why employers are generally not tempted to hire unemployed job applicants at wages below those paid to their existing workforce. Whether this is an explanation - still less the explanation - of mass unemployment is much more questionable. Where does it leave the principle of effective demand, which does not seem to feature (explicitly, at least) anywhere in McDonald's introduction? And how do capitalists implement their dislike of full employment as a threat to 'discipline in the factories', in Kalecki's immortal phrase, if not through their political power over government macroeconomic policy? This raises major questions of political economy, about which McDonald (and his 24 authors) have very little to say.

It is reassuring to read that the 'applications of behavioural economics to macroeconomics contained in this volume tend to a rather gloomy view of capitalism', one which is 'a very different picture from the sunny view presented by mainstream macro' (McDonald 2009: xviii). But I am still inclined to think that behavioural macroeconomics has more to learn from post-Keynesians than they have to teach us.

This conclusion is confirmed by Paul De Grauwe's Lectures on Behavioral Macroeconomics, a slim volume in which De Grauwe replaces the assumption of rational expectations with that of 'animal spirits' - 'waves of optimism and pessimism of investors that have a self-fulfilling property and that drive the movements of investment and output' (De Grauwe 2012, p. 12). This leads him to reject Ricardian Equivalence and instead assert the effectiveness of fiscal policy. His behavioural business cycle is endogenous, money is not neutral and the Phillips Curve is not vertical. But he continues to use the standard three-equation model, which leads him to conclude that the 'need for output stabilisation ... arises exclusively because of price and wage rigidities' (De Grauwe 2012: 69; stress added). De Grauwe's is a strange sort of capitalist economy, with no workers or capitalists, no profits or wages, no employment or unemployment. His 'supply shocks' are confined to unexpected variations in productivity growth, since there is no space in the model for distributional conflict, wage-push inflation or 
fluctuations in primary product prices. De Grauwe's explanation of the Global Financial Crisis is equally circumscribed: it "was not the result of an exogenous shock but resulted from excessive optimism that built up before 2008 and led to unsustainable consumption and investment' (De Grauwe 2012: 125). He has nothing to say about financialisation, the growth of debt, rising inequality in income and wealth, or global imbalances, and it is difficult to see how his model could begin to get to grips with the continuing crisis of the eurozone.

\section{OLD BEHAVIOURAL ECONOMISTS ON MACROECONOMICS}

Herbert Simon is not generally regarded as a macroeconomist, and there are good reasons for this. His work in economics focused primarily on the behaviour of individuals and organisations, and for the most part fits naturally into the literature of microeconomics. In his autobiography, Simon makes three references to Keynes. One is a brief account of the Dahlberg hydraulic model of the economy that sat on his father's desk in 1932 and 'was undoubtedly classical rather than Keynesian' in nature (Simon 1991: 31). In another he relates how in the Graduate School of Industrial Administration (GSIA) at Carnegie Tech he had fallen out with the 'rational expectationists, and the neoclassical mathematical economists generally', who 'gradually made GSIA less and less congenial to me' in the 1960s and precipitated his move out of economics (Simon 1991: 250). In between, there is an intriguing reference to Simon's participation in the Cowles seminars in the late 1940s:

John Maynard Keynes's famous book, The General Theory of Employment, Interest, and Money, wholly verbal and equationless, had mostly baffled me, but now John Hicks, and especially Franco Modigliani, published mathematical models of the Keynesian system that I could understand. I came to understand just enough of monetary theory (a specialty of Modigliani and of Don Patinkin) to know that I did not understand it at all, and to suspect that other economists didn't either. That suspicion lingers with me today. (Simon 1991: 103)

This needs to be taken with a substantial pinch of salt, not least as a record of Simon's own failure to see all the equations in chapter 20 and elsewhere in The General Theory. It would, however, be good to know which 'other economists' he was alluding to.

Simon's last major work on economics, the Raffaele Mattioli lectures that were delivered in 1993 and published - by a minor Italian miracle - only 4 years later, bore the title An Empirically Based Microeconomics (Simon 1997). In the Festschrift that appeared shortly after his death (Augier/March 2004) there are contributions by macroeconomists like Franco Modigliani and John Muth (both former colleagues and, it must be said, antagonists of his at Carnegie Tech), but the index contains only a handful of references to other macroeconomists. ${ }^{3}$ Similarly, in Earl's twovolume collection paying tribute to Simon (Earl 2001a), there are only two articles out of 51 with a macroeconomic focus (by Esther-Miriam Sent and John Sterman), and just a handful of references to Keynes.

But the full story is a little more complicated than this. In the early 1960s Simon was working on the analysis of 'nearly-indecomposable systems' and published two papers

3. There are two to Keynes (both by Peter Earl), one to Nicholas Kaldor (by Richard Day), one to Hyman Minsky (by Earl and Jason Potts), and six to George Shackle (all by Brian Loasby). 
that were directly relevant to macroeconomics: an Econometrica article on aggregation of variables in dynamic systems, co-authored with Albert Ando (Ando/Simon 1961), and a much better-known paper in the Proceedings of the American Philosophical Society on 'The architecture of complexity' (Simon 1962). The latter was later used by Earl (1998) to explore the possibility of a synthesis of post-Keynesian and Sraffian theory. It also has important implications for the problem that has preoccupied me for several years: the mainstream dogma that macroeconomic theory must have 'rigorous microfoundations'. Simon does not address this question directly. Indeed, he could not have been expected to do so, since the microfoundations dogma was not clearly articulated for another decade or so (King 2012; chs 5-6). But he does clearly anticipate its weakness. In complex systems, Simon argued,

... the whole is more than the sum of the parts, not in an ultimate, metaphysical sense, but in the very important pragmatic sense that, given the properties of the parts and the laws of their interaction, it is not a trivial matter to infer the properties of the whole. In the face of complexity, an in-principle reductionist may be at the same time a pragmatic holist. (Simon 1962: 468)

I am unaware of any mainstream macroeconomist who responded to Simon's arguments. They seem also to have escaped the attention of the post-Keynesians, with the sole exception of Peter Earl many years later. By the time the microfoundations dogma had established itself, Simon was thoroughly alienated from academic economics, and he never pressed the point.

In his Mattioli lectures Simon was primarily concerned with microeconomics, as his title suggests. But there are some significant comments on macroeconomics, too. In the first lecture, on 'contemporary choice theory', Simon devotes several pages to a discussion of The General Theory. He suggests that 'a large part of the book is an exercise in neoclassical analysis', which helps to explain its rapid and extensive impact on the thinking of contemporary 'mainstream economists' (Simon 1997: 13). But in his chapter 12 discussion of 'animal spirits', Simon continues, Keynes made 'a more radical departure from the classical framework', which

... constitutes a general challenge to the claim that we can predict economic behavior by determining what the globally rational utility maximizer would do. Only the fear of pronouncing an egregious anachronism prevents me from claiming Keynes, the author of this ringing statement, as the true originator of the economics of bounded rationality' (Simon 1997: 15-16)

The third lecture, with the rather unpromising title 'Seeking empirical data outside the business firm', has a section in which Simon expresses scepticism about the value of econometric estimation techniques and questions the possibility of providing precise measures of macroeconomic variables. The quantity of money, he argues,

... is not something tangible, measurable against the standard kilogram in Paris, but a state of mind - more accurately, a composite state of innumerable minds of people who are forming expectations about the future and borrowing or lending, repaying debts or requesting their debtors to repay, on the basis of these expectations. (Simon 1997: 73)

Regrettably, Simon did not develop these ideas. Macroeconomic issues did, however, feature prominently in the subsequent discussion, with Robin Marris in particular questioning the usefulness of bounded rationality in macroeconomic theory (Simon 1997: 138-139; for Simon's response, see 174-175). Unfortunately Richard Goodwin's contribution to the discussion was not included in the published record (Simon 1997: 169). 
There are no references in the index to the Mattioli lectures to any macroeconomist other than Keynes. It is possible that neither Marris nor Simon was aware of the work of Peter Earl, who in the 1980s had made several attempts, individually and in joint work with Sheila Dow, to incorporate (Old) behavioural ideas into post-Keynesian monetary theory. There was, in fact, a '“Stirling School”, 1979-1984' (Earl/Potts 2004: 320-327) that produced, among other works, Earl's Economic Imagination (1983), Dow and Earl's Money Matters (1982) and an important but neglected paper on George Shackle by Earl and Neil Kay (1985). ${ }^{4}$ The first deals predominantly with microeconomics, while the second makes only limited use of behavioural economics. There are a couple of references to Shackle's rejection of equilibrium modelling, and one to Simon's views on decomposability (Dow/Earl 1982: 116, 135, 145). Chapters 11 and 12 are devoted to Hyman Minsky, but no attempt is made to claim him as a behavioural economist. The Earl and Kay article, which I suspect to have been overlooked by post-Keynesians when it appeared and to have been completely neglected ever since, is the most interesting of the three. It begins by noting that, for Shackle, 'to be meaningful, choice must make a difference to the unfolding skein of events'; it must give rise to surprises. There are important macroeconomic implications: 'For example, the workings of a multiplier process falsify expectations and these surprises may then spark off euphoric or depressing super-multiplier effects'. Thus "one must sacrifice notions pertaining to "given" preferences and technologies and, with them, the stable functions upon which IS-LM macro models ... are built' (Earl/Kay 1985: 34).

Earl and Kay continue by criticising (micro-) reduction, instead advocating a 'holistic' approach to economic theorising on the grounds that '[e]conomic sub-systems, like smoke particles in a demonstration of Brownian Motion, may be moving around in a manner which seems to lack any pattern, yet higher-level economic sub-systems, like a puff of smoke drifting through the air, may be more stable and manageable and consequently explicable' (Earl/Kay 1985: 36). This, they observe, contradicts the practice of 'most economists', who 'have tended to avoid anything which threatens "bottom up", aggregative models and decomposability' (Earl/Kay 1985: 37). And the implications of decomposability may be considerable. Modern financial systems are 'layered', since one bank's assets are another bank's liabilities. This means that 'scrambles for liquidity can be self-cumulating'. Paradoxically, Earl and Kay suggest, this 'may help also to provide justifiable grounds for optimism for example, a layered financial system might turn out to be sectorally segmented in a way which ensured, say, that industrial production and employment were largely immune from a property market crash' (Earl/Kay 1985: 41). Earl later pointed to the potential policy implications of all this. 'Policy makers', he argued, 'may be unable to predict the timing of collapses in confidence, but at least they might develop sets of rules that enhance the decomposability of the financial system and thereby limit the explosiveness of any multiplier effects' (Earl 2001b: xxii; see also Earl 1990; Earl 1998; Earl et al. 2007).

The Stirling School, at least as defined by Earl, came to an end when he moved to the University of Tasmania in 1984. Thereafter his own interests shifted towards microeconomics, partly as a result of teaching commitments and partly due to his

4. Peter Earl reminds me that the 'Stirling School' also included Brian Loasby and (from a later generation) Peter Bird and Clive Spash, while he himself continued to work in the broad area of macroeconomics (see Earl 1990) and Sheila Dow has recently begun to move back into behavioural economics (Peter Earl, personal communications, 6 and 7 September 2012). 
dissatisfaction with the post-Keynesian emphasis on 'what Keynes really meant' (and this was indeed a problem in the 1980s and early 1990s). Subsequently he has found the Journal of Economic Psychology a more welcoming outlet for his work than the Journal of Post Keynesian Economics. ${ }^{5}$ An earlier attempt by the British economist Paul Mosley to apply the principles of satisficing and bounded rationality in the explanation of macroeconomic policy came to nothing (see Mosley 1976). In the United States, another of Simon's disciples, John Sterman, took the project in a slightly different direction, combining bounded rationality with the 'systems dynamics' approach of Jay Forrester, Dana Meadows and Dennis Meadows and an element of (predominantly Old) Keynesian ideas. As early as 1985, Sterman published what he described as 'a behavioural model of the economic long wave', which was reprinted by Earl in his 2001 tribute to Herbert Simon. The 'self-ordering loops' in the model - in essence an extension of the accelerator principle of business investment - were described as reflecting 'empirical work on decisionmaking heuristics and cognitive biases' and as providing 'a firm empirical foundation for behavioural models in economics' (Sterman 1985: 24).

Fifteen years later Sterman published a massive (982-page) management textbook on applications of systems dynamics, which, he claimed, 'enables us to create management flight simulators' (Sterman 2000: vii) for use in the study of 'organisational learning and change, operations management, corporate strategy, and ... a wide range of systems, from supply chains to scientific revolutions' (Sterman 2000: vi). Although the book was intended 'as a text in courses on systems thinking, simulation modelling, complexity, strategic thinking, operations, and industrial engineering, among others' (Sterman 2000: ix), with no mention of economics, it includes some discussion of cyclical fluctuations in business investment. There is a section on investment that stresses ordering and delivery lags and seems to me to be entirely consistent with Kalecki's work in this area (Sterman 2000: 439-445; cf. Sawyer 1985: ch3). But it comes not in a systematic account of macroeconomic theory but rather in a chapter entitled 'Delays', in part IV, 'Tools for modelling dynamics systems'. Similarly, Sterman's version of the multiplier-accelerator model of the cycle is set out in a chapter on 'the management supply chain' (Sterman 2000: 718-721, which cites Samuelson 1939), while the question 'is the business cycle dead?' is posed (and answered in the negative) in a chapter on 'the labour supply chain and the origins of the business cycle' that focuses on a dynamic stock-flow model of managers' labour hiring and utilisation decisions (Sterman 2000: 785-789).

Evidently Sterman's intended readership does not include economists, heterodox or otherwise. He makes very few references to the economic literature, and none to postKeynesian authors. The neglect has been mutual: I do not recall having seen a reference to Sterman's work by any post-Keynesian author, which strikes me as regrettable.

\section{POST-KEYNESIANS ON BEHAVIOURAL ECONOMICS}

What, then, have post-Keynesians had to say on behavioural economics, Old and $\mathrm{New}$ ? This is really a topic for a $\mathrm{PhD}$ thesis rather than a brief section of a paper, and I cannot claim to provide anything more than selective and impressionistic evidence for my conclusion, which is: not much. I can report the results of JSTOR

5. Personal communication, 1 May 2012. It would be interesting to know why most postKeynesians have shown little or no interest in the Journal of Economic Psychology. 
searches in the Journal of Post Keynesian Economics, covering all issues from volume 1 (1978-1979) to volume 29 (2006-2007). ${ }^{6}$ It soon became apparent that looking for references to 'behaviour' or 'behavioural' was pointless, as these generic terms were widely used in many contexts, most of them entirely irrelevant to my present purpose. Confining the search to 'behavioural economics' (UK and US spelling) produced a mere dozen hits, 3 of them in the 1980s, 6 in the 1990s and 3 after 2000. A search for references to Herbert Simon yielded 37 references, mainly in the 1980s (18), then the 1990s (12) and the short 2000s (7). ${ }^{7}$ A search for 'bounded rationality' produced 32 hits, roughly evenly spaced (11 in the 1980s, 9 in the 1990s and 12 since 2000); some of the usual suspects were implicated (John Harvey, Stephen Dunn, Marc Lavoie, David Dequech, Brian Loasby, Donald Katzner).

For nearly 30 years (116 issues) of a journal, or more than 1000 papers, this seems pretty slight. Even broadening the search to terms such as 'consumer sentiment' (23 hits), 'investor sentiment' (24), 'consumer confidence' (79) and 'business confidence' (160) does not alter the conclusion: most post-Keynesians have made little or no reference to, or use of, behavioural economics, at least in that part of their work published in the Journal of Post Keynesian Economics. ${ }^{8}$ How far this has been due to lack of submissions (reflecting a lack of interest in or awareness of behavioural economics by post-Keynesians), and how far actual or perceived editorial policy has led to rejection or failure to submit, is difficult to say. ${ }^{9}$

Finally, I have to confess mea culpa. I completely ignored behavioural economics in my 2002 History of Post Keynesian Economics Since 1936 (King 2002), and the first edition of my Elgar Companion to Post Keynesian Economics (King 2003), which was published in the following year, has no entry on behavioural economics (and no index reference to the term). Obviously the blame for the omission is mine, but in mitigation I can report that none of the colleagues whom I consulted on the Companion commented on it at the time, and none of the contributors found it necessary to refer to bounded rationality or to cite the work of Herbert Simon. The second edition, published earlier this year, represents a significant improvement, on this issue at least.

\section{CONCLUDING REMARKS}

In one sense these are cheering results, for they suggest that there are substantial unexploited opportunities in the largely unexplored border terrain between behavioural economics and post-Keynesian macroeconomics, perhaps also implicating institutional economic theory. There are also, of course, some dangers. It would be unfortunate if the unremitting and relentless individualism of the New Behavioural Economics

6. Here I have to acknowledge once again the very significant contribution of Therese Jefferson. The cut-off for the JSTOR holding is not significant: between 2007 and 2012 the only directly relevant articles are those already cited, by Fung (2006; 2010-2011; 2011), Jefferson/King (2010-2011) and Raines/Leathers (2011).

7. I rejected three instances where John McCombie referred to Simon's - little-known - work on aggregate production functions.

8. By comparison, in the American Economic Review in the same period (1978-2007) there were 259 references to 'consumer confidence' and 496 to 'business confidence'.

9. This suggests an interesting (but potentially very time-consuming) research project, using both bibliometrics and interviews to establish the extent to which post-Keynesian authors have published on behavioural themes in journals other than the Journal of Post Keynesian Economics, and the reasons for their choice of journals for different aspects of their work. 
(Sent 1997; 2004) were to rub off on post-Keynesians, distracting their attention from the social contexts in which people make their important economic decisions. And, as I have argued at length elsewhere (King 2012), it would be a tragedy if post-Keynesians were to interpret behavioural economics as providing 'microfoundations' for their macroeconomics.

But I really should end on a positive note, and stress the opportunities rather than the threats. One priority might be a behavioural approach to monetary theory, with extensions to financial innovation and to Hyman Minsky's analysis of financial instability, and perhaps also to the theory of monetary policy. Another area where behavioural economics might well have interesting macroeconomic implications is in the modelling of aggregate consumption expenditure, with a post-Keynesian assessment of George Katona's contributions being long overdue (Edwards 2012; Hosseini 2011). A third possibility is the incorporation of material from behavioural economics into the theory of business investment: the Old Behaviouralists did at least aspire to the construction of a theory of the firm, and Keynes can legitimately be criticised for neglecting the organisational psychology and sociology of the investment decision. Finally, a case can be made for revisiting Mosley's (1976) application of the core behavioural concepts of satisficing and bounded rationality to the formation of government policy, with the Global Financial Crisis as a potentially important - and fascinating - case study.

\section{REFERENCES}

Akerlof, G. (2007): The missing motivation in macroeconomics, in: American Economic Review, 97(1), 5-36.

Akerlof, G., Shiller, R. (2009): Animal Spirits: How Human Psychology Drives the Economy, and Why It Matters for Global Capitalism, Princeton, NJ: Princeton University Press.

Ando, A., Simon, H.A. (1961): Aggregation of variables in dynamic systems, in: Econometrica, 29(2), 111-138.

Augier, M., March, J.G. (eds) (2004): Models of a Man: Essays in Memory of Herbert A. Simon, Cambridge, MA: MIT Press.

Davidson, P. (2010-2011): Behavioral economists should make a turn and learn from Keynes and Post Keynesian economics, in: Journal of Post Keynesian Economics, 33(2), 251-254.

De Grauwe, P. (2012): Lectures on Behavioral Macroeconomics, Princeton, NJ: Princeton University Press.

Dostaler, G. (2007): Keynes and His Battles, Cheltenham, UK and Northampton, MA: Edward Elgar.

Dostaler, G., Maris, B. (2000): Dr Freud and Mr Keynes on money and capitalism, in: Smithin, J. (ed.), What is Money?, London: Routledge, 235-256.

Dow, S.C., Earl, P.E. (1982): Money Matters: A Keynesian Approach to Monetary Economics, Oxford: Martin Robertson.

Earl, P.E. (1983): The Economic Imagination: Towards a Behavioural Analysis of Choice, Brighton: Wheatsheaf.

Earl, P.E. (1990): Monetary Scenarios: A Modern Approach to Financial Systems, Aldershot, UK and Brookfield, VT: Edward Elgar.

Earl, P.E. (1998): Information, coordination and macroeconomics, in: Information Economics and Policy, 10(3), 331-342.

Earl, P.E. (ed.) (2001a): The Legacy of Herbert Simon in Economic Analysis, Cheltenham, UK and Northampton, MA: Edward Elgar, two volumes.

Earl, P.E. (2001b): Introduction: part I, in: Earl, P.E. (ed.), The Legacy of Herbert Simon in Economic Analysis, Volume I, Cheltenham, UK and Northampton, MA: Edward Elgar, xiii-xxv. 
Earl, P.E., Kay, N.M. (1985): How economists can accept Shackle's critique of economic doctrines without arguing themselves out of their jobs, in: Journal of Economic Studies, 12(1), 34-48.

Earl, P.E., Peng, T.-C., Potts, J. (2007): Decision-rule cascades and the dynamics of speculative bubbles, in: Journal of Economic Psychology, 28(3), 351-364.

Earl, P.E., Potts, J. (2004): Bounded rationality and decomposability: the basis for integrating cognitive and evolutionary economics, in: Augier, M., March, J.G. (eds), Models of a Man: Essays in Memory of Herbert A. Simon, Cambridge, MA: MIT Press, 317-333.

Edwards, J.M. (2012): Observing attitudes, interests, and expectations, in: Maas, H., Morgan, M.S. (eds), Observing the Economy: Historical Perspectives, Durham, NC: Duke University Press, 137-159.

Fung, M.V. (2006): Developments in behavioural finance and experimental economics and Post Keynesian finance theory, in: Journal of Post Keynesian Economics, 29(1), 19-39.

Fung, M.V. (2010-2011): Comments on 'Can Post Keynesians make better use of behavioral economics?', in: Journal of Post Keynesian Economics, 33(2), 235-249.

Fung, M.V. (2011): The potential contribution of behavioural finance to Post Keynesian and institutionalist finance theories, in: Journal of Post Keynesian Economics, 33(4), $555-573$.

Glahe, F.R. (1991): Keynes's General Theory of Employment, Interest, and Money: a Concordance, Savage, MD: Littleman and Rowfeld.

Hosseini, H. (2011): George Katona: a founding father of old behavioural economics, in: Journal of Socio-Economics, 40(6), 977-984.

Jefferson, T., King, J.E. (2010-2011): Can Post Keynesians make better use of behavioral economics?, in: Journal of Post Keynesian Economics, 33(2), 211-234.

King, J.E. (2002): A History of Post Keynesian Economics Since 1936, Cheltenham, UK and Northampton, MA: Edward Elgar.

King, J.E. (ed.) (2003): The Elgar Companion to Post Keynesian Economics, Cheltenham, UK and Northampton, MA: Edward Elgar; 2nd edn 2012.

King, J.E. (2010): Keynes and 'psychology', in: Economic Papers, 29(1), 1-12.

King, J.E. (2012): The Microfoundations Delusion: Metaphor and Dogma in the History of Macroeconomics, Cheltenham, UK and Northampton, MA: Edward Elgar.

McDonald, I.M. (2009): The Global Financial Crisis and behavioural economics, in: Economic Papers, 28(3), 249-254.

McDonald, I.M. (ed.) (2012): Behavioural Macroeconomics, Cheltenham, UK and Northampton, MA: Edward Elgar.

Mosley, P. (1976): Towards a 'satisficing' theory of economic policy, in: Economic Journal, 86(341), 59-72.

Raines, J.P., Leathers, C.G. (2011): Behavioral finance and Post Keynesian-institutionalist theories of financial markets, in: Journal of Post Keynesian Economics, 33(4), 539-553.

Samuelson, P.A. (1939): Interactions between the multiplier analysis and the principle of acceleration, in: Review of Economics and Statistics, 21(2), 75-78.

Santos, A.C. (2011): Behavioural and experimental economics: are they really transforming economics?, in: Cambridge Journal of Economics, 35(4), 705-728.

Sawyer, M.C. (1985): The Economics of Michat Kalecki, Basingstoke: Macmillan.

Sent, E.-M. (1997): Sargent versus Simon: bounded rationality unbound, in: Cambridge Journal of Economics, 21(3), 323-338, reprinted in Earl (2001a), vol. I, 212-227.

Sent, E.-M. (2004): Behavioral economics: how psychology made its (limited) way back into economics, in: History of Political Economy, 36(4), 735-760.

Simon, H.A. (1962): The architecture of complexity, in: Proceedings of the American Philosophical Society, 106(6), 467-482.

Simon, H.A. (1991): Models of My Life, New York: Basic Books.

Simon, H.A. (1997): An Empirically Based Microeconomics, Cambridge, UK: Cambridge University Press. 
242 European Journal of Economics and Economic Policies: Intervention, Vol. 10 No. 2

Sterman, J.D. (1985): A behavioural model of the economic long wave, in: Journal of Economic Behavior and Organization, 6(1), 17-53, reprinted in Earl, P.E. (ed.) (2001a), The Legacy of Herbert Simon in Economic Analysis, vol. II, Cheltenham, UK and Northampton, MA: Edward Elgar, 101-137.

Sterman, J.D. (2000): Business Dynamics: Systems Thinking and Modeling for a Complex World, Boston: Irwin McGraw-Hill.

Winslow, E.G. (1986): Keynes and Freud: psychoanalysis and Keynes's account of the 'animal spirits' of capitalism, in: Social Research, 53(4), 549-578.

Winslow, E.G. (1990): Bloomsbury, Freud, and the vulgar passions, in: Social Research, 57(4), $785-819$. 